\title{
Higher education confronts the 1990s
}

For the past few years Britain's Department of Education and Science has been wrestling with the problem of demographic change and the numbers of schoolteachers required in the 1980s. Intake into primary schools is in rapid decline at present and the number of teachers being trained has already been cut back by about $25 \%$ from its peak value of five years ago; there are more cuts to come-by the year 1981 there could be only a third of the number of teachers in training that there were in 1971. But by 1991, this decline in student population will have worked its way through to the higher education level with equally dramatic implications for the employment of new staffmaybe. It all depends on what happens to the age participation ratio, the percentage of eighteen-year-olds who enter higher education.

This ratio rose dramatically during the 1960 s as new universities and polytechnics came on stream (universities comprise roughly half the higher education sector). In 1964 the ratio was $8.0 \%$, by $196913.7 \%$; since that date the ratio has hovered around the $14 \%$ mark. And where does it go from here? The Department of Education and Science has just issued a discussion document Higher Education into the 1990 s (free from the department) which looks at policy options and predictions. The subject matter is sufficiently important that the document should be read by every one of the more than $80 \%$ of present-day higher-education teachers who will still be in employment fifteen years from now.

The decline in births has been an exclusively workingclass phenomenon these past few years, but it is the middle classes that use higher education in great numbers, so to a certain extent the system is buffered against too drastic a drop; even so it is clear that, other things being equal, there will be a peak in student numbers some time in the 1980 s followed by a steady fall.

Five policy options are put forward, none of them to be seen in isolation from any of the others. Two of them attempt to follow the population by responding in a passive way to the changes. First, the education system could simply expand and contract by the acquisition and disposal of staff and buildings as required. This would be expensive, particularly in the human terms of staff hired and fired-as the department fully recognises. The second version would steer higher education over the hump more economically by the use of temporary accommodation, the hiring of temporary staff, the employment of more educational technology, four-term years and so on.

The other three alternatives, however, call for more intervention. The first would simply break with the Robbins principle that all those able and willing to enter higher education should be enabled to do so. In effect, the hump would be tunnelled through, by clamping down on expansion from now. In the 1980 s many would be denied higher education, but in the 1990 s it would again become more freely available. The second alternative would call for a much more varied mixture of offeringstwo-year courses, part-time courses, deferred entry, more sandwich courses. The third alternative would mean much more active involvement in attempting to change the age structure and social mix of higher education so as to stimulate a new demand for higher education, which would prevent the downturn in the late 1980s. Thus there would be more positive steps to encourage participation by working-class children and some move towards providing educational opportunities later in life.

No one option is favoured in the paper, but Mr Gordon Oakes, Minister of State for Education, has been pushing a rather extreme version of the last option recently-that $50 \%$ of higher education should be reserved within fifteen years for mature students. This seems too much too soon. A major mistake of the 1960 s was the establishment of so many universities in so few years - an expansion which could not be tied in to an orderly expansion of university jobs. As a result too many were hired too rapidly. There is real danger in yet another drastic change in the nature of universities-in some ways potentially more damaging as it would involve all universities, not just new ones. The objective is worthy enough, but the pace seems bound to cause maximum confusion.

But this is not to deny that higher education has a social-policy role to play alongside being a bastion of learning and a home for the enquiring mind. It is surely becoming increasingly the duty of higher education to provide an appropriate environment for less privileged members of the community-and this includes immigrants - to realise their potential. The rapid expansion in the 1960 s did not adequately do that, and so we must look for slow expansion in the next ten years gradually to get to grips with the issue. This is bound to mean that some more privileged students who up to now would have scraped their way into higher education and profited little hy it will have to do without; this seems no great lossan updated Robbins principle to account for changing moods might speak, however contentiously, of students having to be able, willing and deserving in order to participate in higher education. 